\title{
Patterns of primary production and nutrient availability in a Bahamas lagoon with fringing mangroves
}

\author{
Marguerite S. Koch ${ }^{1, *}$, Christopher J. Madden ${ }^{2}$ \\ ${ }^{1}$ Aquatic Plant Ecology Laboratory, Biological Sciences Department, Florida Atlantic University, 777 Glades Road, \\ Boca Raton, Florida 33431, USA
}

${ }^{2}$ South Florida Water Management District, Everglades Division, 3301 Gun Club Rd., West Palm Beach, Florida 33406, USA

\begin{abstract}
The role of submerged autotrophs in the productivity of tropical lagoons and the potential influence of fringing mangroves was investigated by characterizing primary productivity and nutrient patterns in a Bahamas lagoon. Sediment, water, and seagrass tissue nutrient content was determined at 5 sites along a transect from a fringe mangrove to tidal channel site. Productivity of seagrass Thalassia testudium, sandflats, and the mangrove prop-root algal community was measured along the transect using benthic chambers, while phytoplankton and epiphyte production was quantified via light-dark bottle experiments. Sediment phosphorus and nitrogen decreased from $0.24 \pm 0.04$ to $0.09 \pm 0.01$ and $3.23 \pm 1.01$ to $1.44 \pm 0.69 \mathrm{mg} \mathrm{g}^{-1}$ dry wt from the mangrove to seagrass channel site. Nutrient levels in the water column and plant tissues followed a similar spatial trend. Leaf, root, and rhizome C:P molar ratios at the mangrove site $(641 \pm 30,1208 \pm 385$, and $595 \pm 71)$ were low compared to those of the lagoon $(761 \pm 70,2220 \pm 463$, and $1137 \pm 289)$ and channel $(953 \pm 42,2177 \pm 349$, and $2003 \pm 293)$ sites, indicating that seagrass beds adjacent to fringe mangroves have higher nutrient availability. While these nutrient trends were significant, they did not result in higher net community primary production (NPP) in beds adjacent to the mangroves. All seagrass sites had high NPP rates $\left(1.65\right.$ to $\left.2.29 \mathrm{~g} \mathrm{C} \mathrm{m}^{-2} \mathrm{~d}^{-1}\right)$. NPP rates of epiphytes $\left(5.22 \pm 1.44 \mathrm{~g} \mathrm{C} \mathrm{kg}^{-1} \mathrm{~d}^{-1}\right)$ and prop-root algae $\left(8.54 \pm 6.41 \mathrm{~g} \mathrm{C} \mathrm{kg}^{-1} \mathrm{~d}^{-1}\right)$ approached those of seagrass $\left(10.49 \pm 3.76\right.$ to $\left.13.18 \pm 5.68 \mathrm{~g} \mathrm{C} \mathrm{kg}^{-1} \mathrm{~d}^{-1}\right)$. Based on sediment, water column nutrient patterns and tissue stoichiometry, seagrasses in close proximity to the mangrove fringe had the greatest nutrient availability among sites. However, seagrass community NPP rates were similar across the nutrient gradient from the mangroves to the central channel. The fringe mangrove zone supported high algal production rates, contributing to total ecosystem primary production.
\end{abstract}

KEY WORDS: Seagrass · Thalassia $\cdot$ Mangroves $\cdot$ Community Metabolism · Nutrients $\cdot$ Tropics Resale or republication not permitted without written consent of the publisher

\section{INTRODUCTION}

Primary production rates in seagrass communities are among the highest reported for aquatic ecosystems, including salt marshes and coral reefs (Odum 1971, Alongi 1998). Seagrass lagoons and estuaries are recognized as supporting high rates of primary production, but the mechanisms sustaining high productivity

*E-mail: mkoch@fau.edu in oligotrophic tropical environments are currently under debate. Nitrogen fixation has increasingly been recognized as an important source of new nitrogen to support high primary production of tropical seagrasses (Capone 1983, Short et al. 1990, Alongi 1998). An equivalent source of new phosphorus via active fixation is not available to plants, increasing the potential for P limitation in tropical aquatic systems.

Jensen et al. (1998) calculated that dissolved inorganic P pools in porewater and overlying surface water would not sustain a $200 \mathrm{~d}$ growing season in Thalassia

(C) Inter-Research 2001 
testudium seagrass beds in Bermuda. They hypothesized that the inorganic P pool associated with sorption and precipitation with calcium carbonate, primarily fluorapatite, would be an important new source of P to tropical seagrasses via carbonate dissolution. The mobilization of this P source, however, may not be fast enough to eliminate $\mathrm{P}$ limitation in carbonate sediments. Another potential P source for seagrasses is organic $\mathrm{P}$ that is mineralized in the sediments or made available through alkaline phosphatase activity (APA), although APA activities are lower in seagrass than algae and seagrass epiphytes (Lapoint 1989, Pérez \& Romero 1993, Evans \& Koch unpubl. data).

An additional source of nutrients in tropical estuaries and lagoons may be via coupling with adjacent communities. Seagrass lagoons are frequently associated with fringing mangrove communities at the land-sea margin interface or with mangrove islands. Mangrove sediments are characterized by high organic matter, providing important organic substrates for microbial communities (Benner \& Hodson 1985, Alongi 1998) and potential nutrient regeneration. In addition, fringing mangrove prop roots support an abundant epibiont community that recycle water column nutrients and attract high-level consumers that can make additional nutrients available via excretion. Because of the large areal extent of fringing mangroves associated with seagrasses in tropical carbonate lagoons, mangroves may provide an important source of nutrients to adjacent seagrass beds, either directly through detrital mineralization or indirectly through excretion by associated fauna.

Because $\mathrm{P}$ has been shown to limit autotrophic production in tropical carbonate systems (Short et al. 1985, 1990, Lapointe 1987, Powell et al. 1989, 1991, Fourqurean et al. 1992a,b), we suggest that $\mathrm{P}$ acquisition, controlled by high nutrient availability in the fringing mangroves, would enhance tissue nutrient content, and possibly primary production, in seagrasses adjacent to mangrove communities. Furthermore, we hypothesize that these nutrients would support high benthic and epiphytic algal productivity within the mangrove prop-root zone. To seek support for this idea in potential patterns of nutrient availability and primary production, we quantified water column and sediment nutrients ( $\mathrm{P}$ and $\mathrm{N})$, and seagrass and epiphyte tissue nutrients along a transect from fringing mangroves to a seagrass channel at Grand Bahama Island. Along this tran- sect, we quantified community metabolism of the dominant autotrophs: seagrass, seagrass epiphytes, proproot algae, phytoplankton, and benthic algae. The Bahamas location provided an excellent study site because it is oligotrophic and remote from anthropogenic and terrestrial sources of nutrients.

\section{MATERIALS AND METHODS}

Study site. Eastern Grand Bahama Island is characterized by extensive, shallow $(<3 \mathrm{~m})$ lagoons created by tidal inlets traversing the island (Fig. 1). These lagoons are fringed by mangroves and interspersed with numerous mangrove islands dominated by Rhizophora mangle ( 3 to $5 \mathrm{~m}$ height). Our study site at Sweeting's Cay (Fig. 1) was chosen for its pristine state, lack of nearby human settlements, and extensive seagrass beds and fringing mangroves. Five sites were selected along a transect (130 m length) from the fringe mangroves (10 m width) to the central tidal channel (Fig. 1). Sites were established in fringe mangroves (M), a seagrass bed adjacent to the fringe mangroves (MSG), an unvegetated sand flat in the central lagoon (SF), a seagrass bed in the central lagoon (LSG), and a seagrass bed at the channel margin (CSG). Water depth averaged approximately $0.25 \mathrm{~m}$ at the $\mathrm{M}$ site, $0.5 \mathrm{~m}$ at the MSG, SF, and LSG sites, and $0.75 \mathrm{~m}$ at the CSG site. At each site, benthic community metabolism was determined from measurements of dissolved oxygen flux within clear and dark benthic chambers.

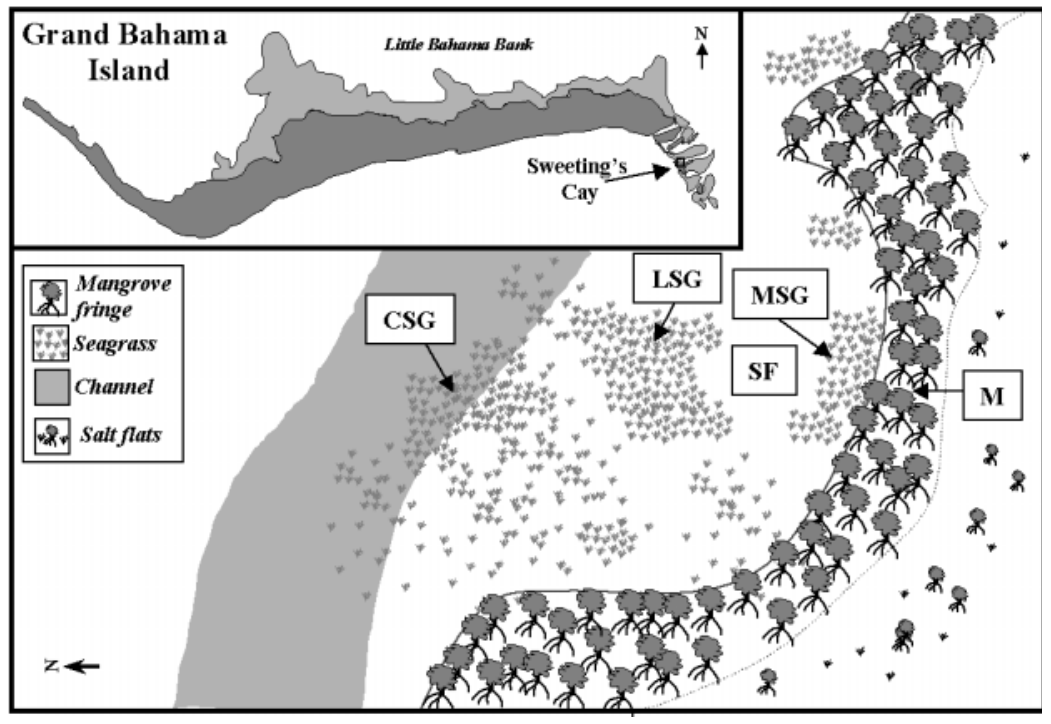

Fig. 1. Inset: Grand Bahama Island depicting low-elevation areas (light gray) and Sweeting's Cay (arrow). The shallow tidal channel $(<3 \mathrm{~m})$ and adjacent lagoon are enlarged to identify the 5 study sites: fringe mangrove (M), mangrove seagrass (MSG), lagoon sand flat (SF), lagoon seagrass (LSG), and channel seagrass (CSG) 
Chambers were also used to determine the productivity and respiration rates of the mangrove prop-root algal community.
Productivity chamber construction. Community metabolism chambers (Fig. 2a,b) were designed to operate autonomously as closed systems using submersible

\section{Light Incubations}
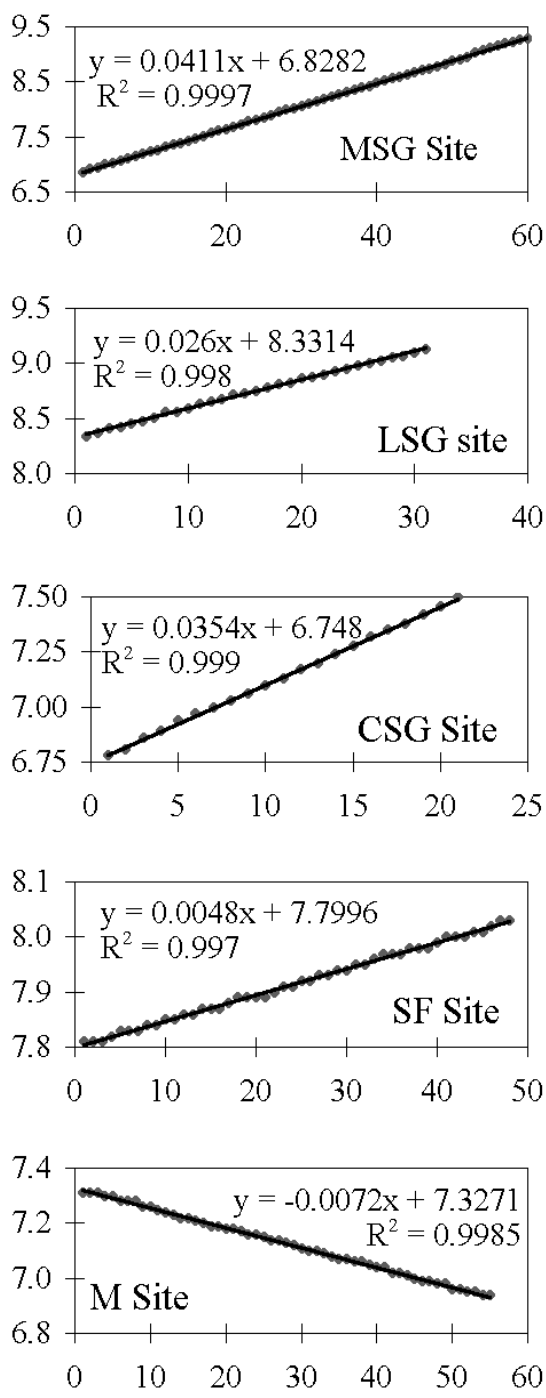

(a)

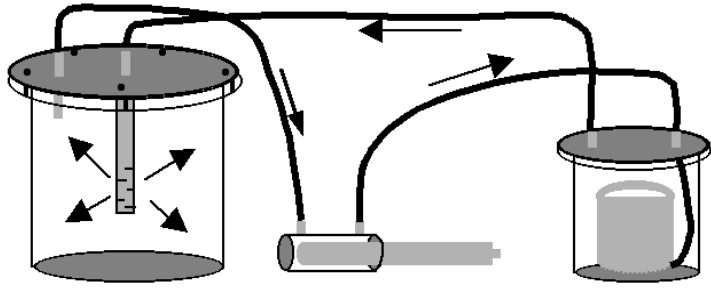

\section{Dark Incubations}
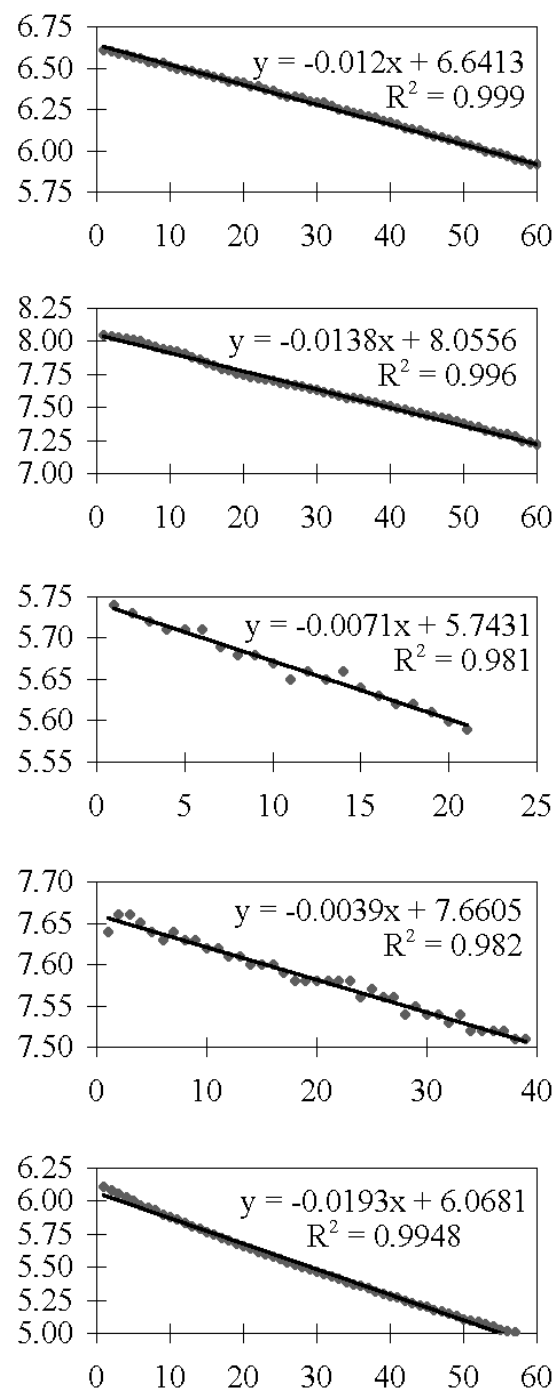

(b)

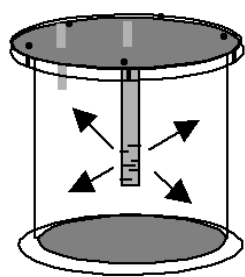

Fig. 2. Oxygen flux ( $\mathrm{mg} \mathrm{O}_{2} \mathrm{l}^{-1}$ : ordinates) over time (min: abscissas) in benthic chambers incubated in light and dark conditions from fringe mangrove (M), mangrove seagrass (MSG), lagoon sand flat (SF), lagoon seagrass (LSG), and channel seagrass (CSG) sites. Linear regression equations presented with $\mathrm{R}^{2}$. (a) Schematic of benthic chamber, illustrating water circulation patterns (arrows) from the battery-operated pump (small chamber on right) to the incubation chamber (large chamber, on left) distribution tube to the data-recorder flow cell as a closed system; (b) prop-root algal chambers with O-ring sealed top and bottom and the same circulation pattern as in (a) 
battery-operated pumps (Attwood Inc.) and in situ polarographic $\mathrm{O}_{2}$ recorders (YSI 600 XLM, YSI Inc.). Clear Plexiglas chambers were covered on the outside with marine-grade black vinyl to fabricate dark respiration chambers. The chambers $(20 \mathrm{~cm}$ diameter) are modular, so $30 \mathrm{~cm}$-high sections can be stacked to allow for various-height SAV (submerged aquatic vegetation) species. Because of the low-stature plants in our study area ( 20 to $30 \mathrm{~cm}$ leaf lengths), a single $30 \mathrm{~cm}$ section was used for measurements. Water turnover rate in the single unit chamber was approximately once every $2 \mathrm{~min}$.

Light environment. Incubations were conducted in situ under natural light from May 17, 18, 19, 22 and 23, 1998. Insolation was recorded every 5 min using a shipboard Li-Cor LI-1000 quantum radiometer and terrestrial flat sensor measuring the wavelengths of photosynthetically active radiation (PAR, 400 to $700 \mathrm{~nm}$ ). Light in the water column was measured continuously in the lagoon using spherical $(4 \pi)$ underwater sensors deployed at 2 depths (subsurface and canopy height). Spherical sensors were used due to the considerable upwelling and side-welling radiation in the shallow, carbonate system. Water column vertical attenuation was calculated from the difference in irradiance between the 2 depths, and by solving for $K$ in the Lambert-Beers equation, $K=\ln \left(I_{2} / I_{1}\right) / D$, where $I$ is PAR at 2 depths and $D$ is the vertical distance between sensors. It was assumed that the subsurface light environment at all sites was similar, except within the mangrove prop-roots (Site M), where additional PAR sensors were deployed.

The ambient light environment was similar during all incubations (11:00 to 16:00 h) May 17, 18, 19, 22 and 23, with mean PAR for each day ranging from 1204 to $1298 \mu \mathrm{mol} \mathrm{m} \mathrm{m}^{-2} \mathrm{~s}^{-1}$ during daylight hours. Maximum daily irradiance during the experiment ranged from 1980 to $2112 \mu \mathrm{mol} \mathrm{m}{ }^{-2} \mathrm{~s}^{-1}$, averaging $2060 \mu \mathrm{mol} \mathrm{m}{ }^{-2} \mathrm{~s}^{-1}$ just after 13:00 $\mathrm{h}$ (solar noon) on each day. To reduce the possibility that light would have a significant effect on photosynthesis rates, all incubations were conducted within $3 \mathrm{~h}$ of solar noon. The water column vertical attenuation coefficient $(K)$ was low, averaging $0.31 \mathrm{~m}^{-1}$ over all days, indicating a high degree of transparency in the lagoon. Although light levels within the mangrove prop-root zone were reduced, averaging only $1500 \mu \mathrm{mol} \mathrm{m}{ }^{-2} \mathrm{~s}^{-1}$ at midday, the attenuation coefficient $(\mathrm{K})$ in these waters was also low (averaging $0.20 \mathrm{~m}^{-1}$ ).

Productivity incubations. Both light and dark chamber $\left(11.43 l_{;} ; 24.3 \mathrm{~cm}^{2}\right)$ incubations were conducted for approximately 20 to $60 \mathrm{~min}$, recording dissolved $\mathrm{O}_{2}$ concentration $\left(\mathrm{mg} \mathrm{l}^{-1}\right)$ every minute. High temporal resolution of $\mathrm{O}_{2}$ changes in the chambers resulted in a good linear fit for light and dark incubations at all sites (Fig. 2). Of a total 44 light and dark incubations, the median $\mathrm{R}^{2}$ was 0.995 , with $80 \%$ of $\mathrm{R}^{2} \geq 0.98$. Although $\mathrm{O}_{2}$ concentrations were $>100 \%$ saturation during incubations, no depression in the slope was observed over time, suggesting that super-saturation did not adversely affect the measurements (Fig. 2: left-hand graphs). Few bubbles were observed in the chambers, and then only when incubations were nearly complete. The water outside the chambers also remained close to or above $\mathrm{O}_{2}$ saturation at all sites during the incubation period (Table 1), indicating that this is a natural condition of the lagoon. High $\mathrm{O}_{2}$ saturation was primarily influenced by high temperature and salinity. $\mathrm{O}_{2}$ concentrations ranged between 6.4 and $7.5 \mathrm{mg} \mathrm{l}^{-1}$ (Table 1). Given the high rates of photosynthesis we measured, it appears that benthic plants were acclimated to extremes of $\mathrm{O}_{2}$, temperature, and salinity. However, we recognized that our $\mathrm{O}_{2}$ production rates might have been slightly underestimated because of $\mathrm{O}_{2}$ super-saturation, and attempted to minimize the effect by maintaining short incubations.

To determine photosynthetic rates, $\mathrm{O}_{2}$ fluxes were converted to carbon equivalents using a photosynthetic quotient of 1.2 and a respiratory quotient of 1.0. Daily respiration rates were calculated over $24 \mathrm{~h}$, and photosynthesis over a $10 \mathrm{~h}$ light cycle (based on light readings above $500 \mu \mathrm{mol}$ PAR $\mathrm{m}^{-2} \mathrm{~s}^{-1}$ from approximately 08:00 to 18:00 h). We used a coefficient of 0.9 to

Table 1. Environmental conditions in the overlying water column prior to each incubation at the fringe mangrove (M), mangrove seagrass (MSG), lagoon seagrass (LSG), and channel seagrass (CSG) sites. The time period during which all incubations were performed during the $5 \mathrm{~d}$ of measurement is given. Data are means $\pm \mathrm{SD} ; \mathrm{n}=$ number of incubations at each site

\begin{tabular}{|c|c|c|c|c|c|c|c|}
\hline Site & $\mathrm{n}$ & Time & $\begin{array}{c}\mathrm{O}_{2} \\
\text { (\% sat) }\end{array}$ & $\begin{array}{c}\mathrm{O}_{2} \\
\left(\mathrm{mg} \mathrm{l}^{-1}\right)\end{array}$ & $\begin{array}{c}T \\
\left({ }^{\circ} \mathrm{C}\right)\end{array}$ & $\begin{array}{c}\text { Salinity } \\
\text { (PSU) }\end{array}$ & $\mathrm{pH}$ \\
\hline$M^{\mathrm{a}}$ & 17 & $11: 32-16: 00$ & $123 \pm 12$ & $7.47 \pm 0.66$ & $29.8 \pm 1.12$ & $38.8 \pm 0.4$ & $8.17 \pm 0.06$ \\
\hline $\mathrm{MSG}^{\mathrm{b}}$ & 12 & $11: 49-15: 07$ & $115 \pm 12$ & $7.27 \pm 0.66$ & $27.8 \pm 1.96$ & $38.9 \pm 0.4$ & $8.17 \pm 0.05$ \\
\hline $\mathrm{LSG}^{\mathrm{c}}$ & 12 & $11: 13-15: 27$ & $119 \pm 12$ & $7.63 \pm 0.78$ & $27.0 \pm 0.75$ & $39.2 \pm 0.4$ & $8.24 \pm 0.02$ \\
\hline $\mathrm{CSG}$ & 4 & $10: 32-13: 01$ & $98 \pm 5$ & $6.42 \pm 0.38$ & $25.9 \pm 0.26$ & $38.8 \pm 0.4$ & $8.18 \pm 0.05$ \\
\hline \multicolumn{8}{|c|}{$\begin{array}{l}\text { ancludes M sediment and prop-root algal incubations } \\
\text { bIncludes MSG and MSG sand-flat incubations }\end{array}$} \\
\hline
\end{tabular}


account for decreases in photosynthesis early and late in the day (Shaffer \& Onuf 1985, Randall \& Day 1987). At each site, we conducted at least replicate benthic chamber seagrass incubations.

Production and respiration rates of the mangrove prop-root algae were measured by reconfiguring the chambers with 2 sealed O-ring tops at both ends (Fig. 2b), and inserting a section $(\sim 20 \mathrm{~cm})$ of prop-root with the entire epibiont community, including the associated macroalgae. Prop-roots alone were also incubated, and $\mathrm{O}_{2}$ consumption rates were subtracted from incubations with the epibiont community to account for prop-root respiration. Within the sealed chamber, no $\mathrm{O}_{2}$ leakage in the form of bubbles was observed from the prop-root section where it was excised from the tree; in addition, only 1 end was cut to reduce the potential effects on $\mathrm{O}_{2}$ flux.

Phytoplankton and epiphyte metabolism was determined under in situ conditions in $300 \mathrm{ml}$ incubation bottles under light and dark conditions at ambient temperatures $\left(27\right.$ to $29^{\circ} \mathrm{C}$ ) and saturating light $>1000 \mu \mathrm{mol}$ PAR $\mathrm{m}^{-2} \mathrm{~s}^{-1}$. Epiphytes scraped from $10 \mathrm{~cm}$ sections of 6 Thalassia testudium leaves from the MSG site and phytoplankton were incubated for approximately $4 \mathrm{~h}$, and initial and final $\mathrm{O}_{2}$ concentrations were measured.

Sediment and water analyses. Four replicate sediment cores (5 cm diameter PVC) were extracted from each site, transported to the ship (RV 'Bellows'), and kept on ice until we returned to the laboratory (approximately $5 \mathrm{~d}$ ). Because of the time lag between extracting and sectioning cores, porewater nutrient analysis was not undertaken. Sediment cores were sectioned into 0 to 5 and 5 to $20 \mathrm{~cm}$ depth increments, weighed, and a sub-sample ( 10 g dry wt) taken for drying and ashing to determine bulk density $\left(\mathrm{g} \mathrm{cm}^{-3}\right)$ and ash-free dry wt $\left(\mathrm{g} \mathrm{g} \mathrm{g}^{-1}\right)$. Dried sediments were subsequently ground, and analyzed for total nitrogen (TN) and total carbon (TC) on a CNS elemental analyzer (Fisons Instrument NA 1500). A sub-sample of dried sediment was weighed with a precision of $1 \mu \mathrm{g}$, oxidized at $450^{\circ} \mathrm{C}$ for $12 \mathrm{~h}$, reweighed, and analyzed on the elemental analyzer for total inorganic C. Organic C was calculated as the difference between total and inorganic C. Total P (TP) was determined by placing $1.00 \mathrm{~g}$ of sediment in borosilicate culture tubes and combusting the tubes at $550^{\circ} \mathrm{C}$ in a muffle furnace. Culture tubes were cooled and $15 \mathrm{ml}$ of $5 \mathrm{~N} \mathrm{HCl}$ was slowly added. Tubes were autoclaved at $121^{\circ} \mathrm{C}$ and 21 psi for $50 \mathrm{~min}$. The contents of each tube were filtered and brought to a final volume of $50 \mathrm{ml}$ and measured spectrophotometrically (Shimadzu UV-1601) for SRP (soluble reactive $\mathrm{P}$ ) using the molybdate complex standard method (APHA 1995).

Surface water samples (1 l) were taken on slack flood tide in triplicate from 3 parts of the lagoon: fringe man- grove, central lagoon, and channel. Water samples were kept on ice and transported to the ship, where they were filtered $(0.45 \mu \mathrm{m})$ and immediately frozen. Upon return to the laboratory, they were thawed and immediately run on an autoanalyzer (Perstorp Inc.) for nitrate + nitrite $\left(\mathrm{NO}_{\mathrm{x}}\right), \mathrm{SRP}$, and $\mathrm{NH}_{4}{ }^{+}$, using standard methods (APHA 1995). Overlying surface waters were also sampled before each incubation for $\mathrm{O}_{2}\left(\mathrm{mg} \mathrm{l}^{-1}\right)$, temperature $\left({ }^{\circ} \mathrm{C}\right)$, salinity (PSU), and $\mathrm{pH}$ with recording sondes (YSI 600 XLM, YSI Inc.).

Plant nutrient analyses. Four replicate plant cores (15 cm diameter) with intact sediments to a depth of $20 \mathrm{~cm}$ were extracted from each of the seagrass sites (MSG, LSG, and CSG) and taken to the ship, where below- and above-ground tissues were separated from sediments. The dominant plant in each core was Thalassia testudinum (>99\%), so no effort was made to analyze nutrients for any other seagrass or algal species, however seagrass epiphytes were analyzed. T. testudinum plant tissues from each core, with epiphytes removed, were rinsed in deionized water and frozen. In the laboratory, tissues were dried to constant weight $\left(65^{\circ} \mathrm{C}\right)$, ground in a mortar and pestle, and sieved $(40$ mesh); below-ground tissues were separated into roots and rhizomes before processing. To sample epiphytes, seagrass leaves were carefully cut and placed in plastic bags and transported to the ship, where leaves were removed from bags and all epiphytes scraped onto foil sheets with a spatula. These samples were then processed as above for tissue analysis, with the exception of inorganic and organic $\mathrm{C}$ analyses, which were processed in the same manner as the sediments.

Statistical analyses. Forty-four chamber production and respiration incubations were conducted with replicate or triplicate incubations per site. Linear regression analysis was used to calculate the slope of $\mathrm{O}_{2}$ change over time for each incubation to determine metabolism rates (Fig. 2). Seagrass/epiphyte tissue and sediment nutrients and sediment characteristics were compared among sites using ANOVA ( $\mathrm{p}<0.05$ for significance) and Scheffé's multiple mean comparisons using a $99 \%$ confidence limit ( $p<0.01)$. All means in the text and illustrations are reported with $\pm 1 \mathrm{SD}$.

\section{RESULTS}

\section{Sediment and water column nutrients}

Sediment TP concentrations at both 0 to 5 and 5 to $20 \mathrm{~cm}$ depths were significantly higher at the fringe mangrove site than at all seagrass and sand flat sites (Fig. 3a). Sediment TP concentrations were also elevated in the seagrass site adjacent to the mangroves (MSG) compared to the channel bank site (CSG, Fig. 3a). Fewer 


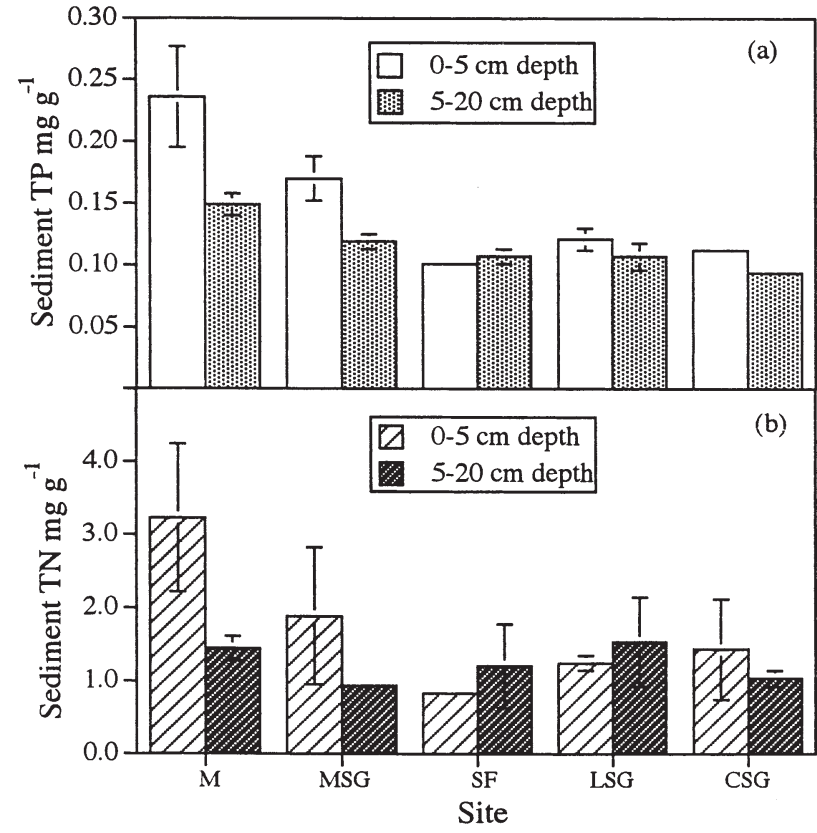

Fig. 3. Total sediment phosphorus (TP) and nitrogen (TN) from 0 to 5 and 5 to $20 \mathrm{~cm}$ depths in the fringe mangrove (M), seagrass bed adjacent to the fringe mangroves (MSG), unvegetated sand flat in the central lagoon (SF), seagrass bed in the central lagoon (LSG), and seagrass bed at the channel margin (CSG) sites

significant differences among sites were found for TN as a result of high variance, but similar trends were observed (Fig. 3b). TN at the 0 to $5 \mathrm{~cm}$ depth was significantly higher at the fringe mangrove site (M) than the sandflat (SF) site. ANOVA among sites for TN was non-significant below $5 \mathrm{~cm}$.

Site differences in sediment nutrient concentration ( $\mathrm{mg} \mathrm{g}^{-1}$, Fig. 3) cannot be attributed to variation in bulk density, because sediment bulk density was similar among all sites and depths (Table 2). High inorganic carbon (C) content $(89 \%)$ of the sediments accounted for the high bulk density (Table 2). While the inorganic and organic C content of sediments was similar at all sites below $5 \mathrm{~cm}$ depth, organic C was 3-fold greater at the mangrove site at 0 to $5 \mathrm{~cm}$ (Table 2).

Water column $\mathrm{NO}_{\mathrm{x}}, \mathrm{SRP}$, and $\mathrm{NH}_{4}{ }^{+}$ concentrations were highest within the fringe mangroves (Fig. 4), as were sediment nutrients, but all sites had low $(<0.5 \mu \mathrm{M})$ water column nutrients, consistent with the oligotrophic status of the lagoon.

\section{Plant nutrients}

Phosphorus content in live leaf (LL) tissues of Thalassia testudinum declined from the fringe to the channel sites: P content was $1.90 \pm 0.03,1.09 \pm 0.10$, and $0.90 \pm$ $0.05 \mathrm{mg} \mathrm{P} \mathrm{g}^{-1}$ dry wt at the mangrove (MSG), lagoon, (LSG), and channel (CSG) sites, respectively. The opposite trend was found for tissue $\mathrm{C}$ content, increasing with distance from the mangroves: $296 \pm 11,319 \pm 12$, and $333 \pm 6 \mathrm{mg} \mathrm{g}^{-1}$ dry wt. This resulted in leaf tissue $\mathrm{C}: \mathrm{P}$ molar ratios markedly increasing from the fringe mangrove to channel sites from about 600 to nearly 1000 (Fig. 5). Root and rhizome C:P ratios followed a similar increasing trend (Fig. 5), while $\mathrm{C}$ content of the roots (range: $275 \pm 11$ to $282 \pm 4 \mathrm{mg} \mathrm{g}^{-1}$ dry wt) and rhizomes (range: $295 \pm 26$ to $313 \pm 11$ ) remained the same between sites.

Thalassia testudinum may be preferentially allocating $\mathrm{N}$ to the leaves, because although $\mathrm{C}: \mathrm{N}$ ratios in leaves were similar across sites (Fig. 5), C:N ratios in roots and rhizomes suggest greater $\mathrm{N}$ availability at the fringe mangrove and lagoon sites (Fig. 5). Root $N$ content was similar at the lagoon (LSG: $11.7 \pm 0.84 \mathrm{mg} \mathrm{g}^{-1}$ dry wt) and mangrove (MSG: $10.8 \pm 1.76 \mathrm{mg} \mathrm{g}^{-1}$ dry wt) sites, but lower in the channel (CSG: $8.47 \pm 0.54 \mathrm{mg} \mathrm{g}^{-1}$ dry wt) site, while root $\mathrm{P}$ was greater at the mangrove $(0.64 \pm$ $0.21 \mathrm{mg} \mathrm{g}^{-1}$ dry wt) than at the lagoon $\left(0.34 \pm 0.06 \mathrm{mg} \mathrm{g}^{-1}\right.$ dry wt) and channel $\left(0.34 \pm 0.07 \mathrm{mg} \mathrm{g}^{-1}\right.$ dry wt) sites. These data explain the higher N:P ratios in roots from the lagoon compared to mangrove or channel sites (Fig. 5).

Table 2. Sediment and epiphyte inorganic (IC), organic (OC), and total (TC) carbon content at the fringe mangrove (M), mangrove seagrass (MSG), sand flat (SF), lagoon seagrass (LSG), and channel seagrass (CSG) sites. Bulk density and epiphyte load are shown for sediment and epiphytes, respectively. Data are means $\pm \mathrm{SD}(\mathrm{n}=4)$

\begin{tabular}{|c|c|c|c|c|}
\hline \multirow[t]{2}{*}{ Site } & \multicolumn{3}{|c|}{ Carbon (mg g ${ }^{-1}$ dry wt) } & \multirow{2}{*}{$\begin{array}{l}\text { Bulk density } \\
\qquad\left(\mathrm{g} \mathrm{cm}^{-3}\right)\end{array}$} \\
\hline & IC & $\mathrm{OC}$ & $\mathrm{TC}$ & \\
\hline \multicolumn{5}{|l|}{ Sediment } \\
\hline \multicolumn{5}{|c|}{ Depth $0-5 \mathrm{~cm}$} \\
\hline M & $109 \pm 2.7$ & $31 \pm 2.8$ & $139 \pm 1.8$ & $0.46 \pm 0.11$ \\
\hline MSG & $112 \pm 0.7$ & $11 \pm 2.1$ & $123 \pm 1.5$ & $0.64 \pm 0.12$ \\
\hline SF & $114 \pm 0.9$ & $6 \pm 1.1$ & $120 \pm 1.7$ & $0.62 \pm 0.06$ \\
\hline LSG & $113 \pm 0.3$ & $10 \pm 0.5$ & $123 \pm 0.7$ & $0.55 \pm 0.08$ \\
\hline CSG & $111 \pm 1.4$ & $12 \pm 1.7$ & $123 \pm 0.7$ & $0.53 \pm 0.07$ \\
\hline \multicolumn{5}{|c|}{ Depth 5-20 cm } \\
\hline M & $113 \pm 0.7$ & $14 \pm 2.1$ & $127 \pm 1.5$ & $0.65 \pm 0.10$ \\
\hline MSG & $110 \pm 3.8$ & $14 \pm 2.0$ & $121 \pm 0.1$ & $0.73 \pm 0.06$ \\
\hline SF & $114 \pm 0.9$ & $9 \pm 2.0$ & $122 \pm 1.1$ & $0.69 \pm 0.03$ \\
\hline LSG & $113 \pm 0.5$ & $9 \pm 0.8$ & $123 \pm 0.5$ & $0.72 \pm 0.08$ \\
\hline CSG & $112 \pm 0.6$ & $11 \pm 1.0$ & $122 \pm 0.5$ & $0.62 \pm 0.12$ \\
\hline Epiphytes & \multicolumn{4}{|c|}{ Epiphyte load $\left(\mathrm{g} \mathrm{m}^{-2}\right)$} \\
\hline MSG & $104 \pm 1.4$ & $46 \pm 5.3$ & $151 \pm 3.3$ & $328.0 \pm 31.8$ \\
\hline LSG & $109 \pm 6.0$ & $28 \pm 5.9$ & $137 \pm 0.3$ & $73.1 \pm 27.7$ \\
\hline CSG & $106 \pm 3.5$ & $36 \pm 6.3$ & $143 \pm 10.5$ & $8.8 \pm 1.9$ \\
\hline
\end{tabular}




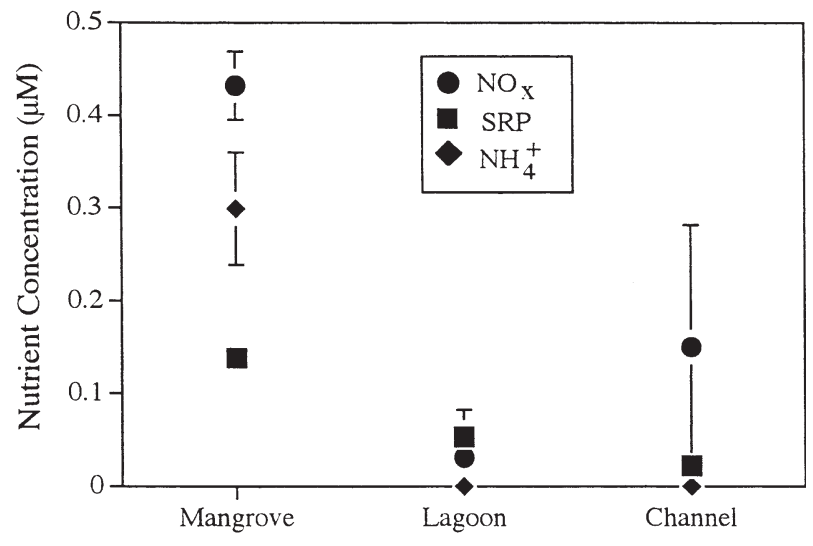

Fig. 4. Surface water nitrate + nitrite $\left(\mathrm{NO}_{\mathrm{x}}\right)$, soluble reactive phosphorus (SRP), and ammonium $\left(\mathrm{NH}_{4}{ }^{+}\right)$concentration within the fringe mangrove, central lagoon, and channel at the study site

In contrast to Thalassia testudinum tissue, epiphyte organic C:P molar ratios were not significantly different across sites (Fig. 5); however, epiphyte load was 5 and 36 times greater on seagrasses adjacent to the fringing mangroves than within the central lagoon or channel (Table 2). Thus, although the C:P ratios were similar at all sites, the total $\mathrm{P}$ pool in the epiphytes was higher at the MSG (111 $\mathrm{mg} \mathrm{P} \mathrm{m}^{-2}$ ) than at the LSG (16 $\mathrm{mg} \mathrm{P} \mathrm{m}^{-2}$ ), and CSG (2 $\mathrm{mg} \mathrm{P} \mathrm{m}^{-2}$ ) sites. The high epiphyte load at the mangrove fringe cannot be explained by greater T. testudinum biomass, because above-ground biomass was similar among sites (range: $119 \pm 15$ to $143 \pm$ $15 \mathrm{~g}$ dry $\mathrm{wt} \mathrm{m}^{-2}$ ). Epiphytes collected at the MSG site were also high in organic content (Table 2), suggesting a greater biotic component than at sites farther from the mangroves. In addition, the nitrogen content of these epiphytes was high, based on $\mathrm{C}: \mathrm{N}$ ratios (Fig. 5).

\section{Community production and respiration}

On an area and dry weight basis, Thalassia testudinum dominated primary production in the lagoon (Fig. 6), while water column (phytoplankton) production was heterotrophic (Fig. 6a). Seagrass beds from the mangrove, lagoon, and channel sites showed similar patterns of net production rates on an area and dry weight basis (Fig. 6). Although net production rates were similar, gross rates suggest a pattern of increasing production proximate to the fringing mangroves, particularly when normalized to biomass.

In addition to high production rates within the seagrass community, both the epibiont algal flora on fringing mangrove prop-roots and seagrass epiphytes contribute to lagoon primary production (Fig. 6). Epiphytic algae on the mangrove prop-roots was dominated by branched non-filamentous algal functional forms (e.g., species of Laurencia, Batophora, Acetabularia, Bostrychia, Hypnea, Dictyota, Caulerpa: Littler et al. 1983) and were spatially variable in 2 dimensions: vertically on the prop-root in the water column, and horizontally as a function of prop-root density. Because of this spatial heterogeneity, productivity rates for prop-root algae were normalized to algal dry weight. On a biomass basis, the gross primary production (GPP) of prop-root algae was similar to that for the channel seagrass site, and 2 times greater than for seagrass epiphytes (Fig. 6b).

The highest respiration rates in the lagoon were found in the fringing mangrove sediments $(\mathrm{M})$, resulting in a negative NPP rate. However, benthic algal production associated with these sediments maintained a rate of GPP on par with the seagrass beds. Benthic algae within the mangrove fringe were dominated by filamentous forms of macroalgae (e.g., Chaetomorpha sp.: Littler et al. 1983); unfortunately, the patchiness of this algae and entanglement with mangrove detritus

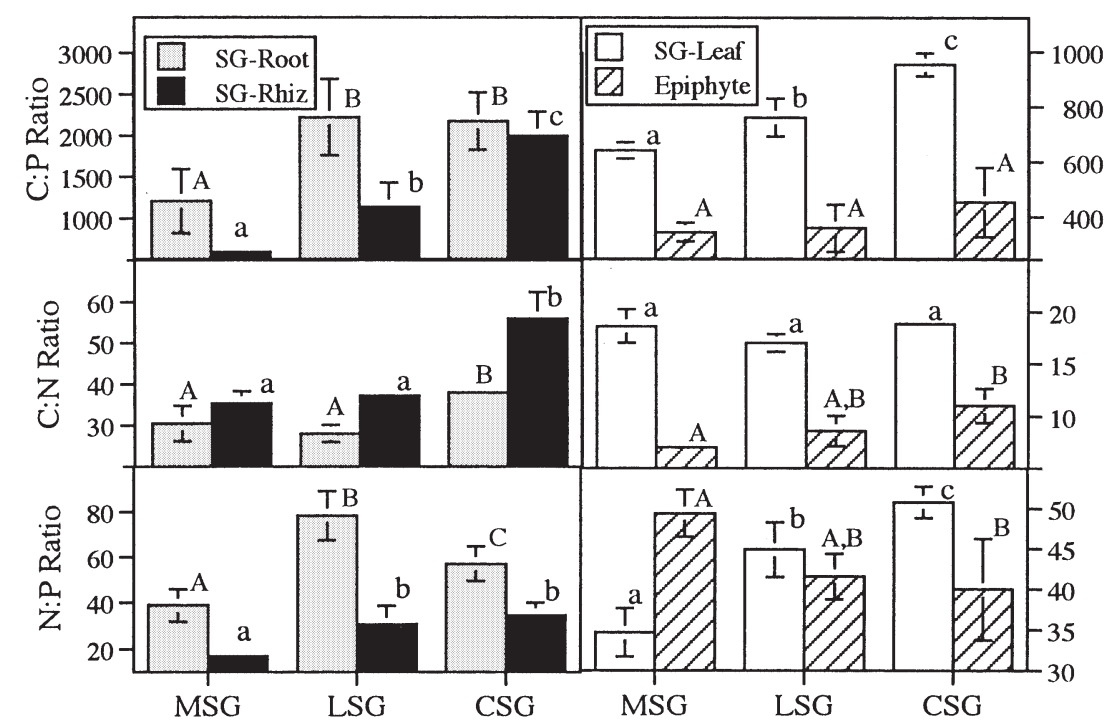

Fig. 5. Epiphyte and Thalassia testudinum (seagrass, SG) live leaf, root and rhizome organic carbon to phosphorus $(\mathrm{C}: \mathrm{P})$ and nitrogen $(\mathrm{C}: \mathrm{N})$ and $\mathrm{N}: \mathrm{P}$ molar ratios from the seagrass beds adjacent to the fringe mangroves (MSG), in the central lagoon (LSG), and at the channel margin (CSG). Different letters within each graph represent significant differences $(p<0.01)$ between sites 


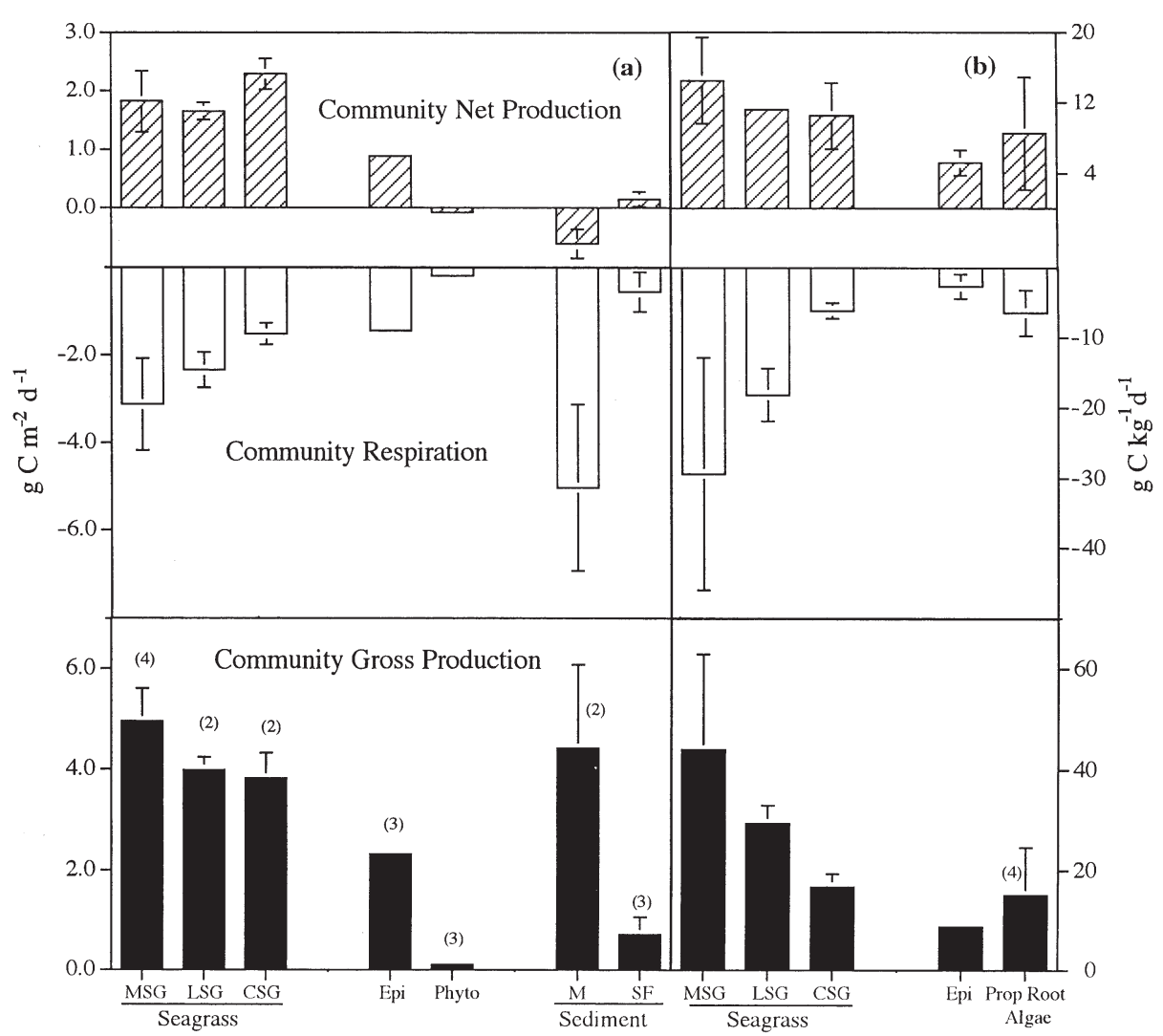

Fig. 6. Daily net and gross community production and respiration rates normalized to (a) area and (b) gram dry wt. Sites with vegetation comprise 3 seagrass Thalassia testudium sites: adjacent to the fringe mangroves (MSG), in the central lagoon (LSG), and at the channel margin (CSG) and prop-root algae; non-vegetated sediment sites comprise the fringing mangrove (M) and sand flat (SF) within the central lagoon. Seagrass epiphytes (Epi) and phytoplankton (Phyto) metabolic rates were determined in closed chambers and extrapolated to an area basis. Numbers in the bottom graphs: number of paired light and dark incubations at each site

made quantifying the biomass of this autotrophic component problematic. In contrast to highly productive benthic algae in the fringe mangrove zone, benthic microalgae in association with sparse patches of the macroalga Batophora sp. on sand flats had low NPP and GPP rates (Fig. 6a). Sand flats also exhibited the lowest rates of benthic respiration.

\section{DISCUSSION}

Thalassia testudinum leaf P content was low at our Bahamas site compared to T. testudinum at other sites and compared to other seagrass species (Duarte 1990, see present Fig. 7), identifying these sites as potentially P-limited. Sediment, water column, and seagrass tissue $\mathrm{P}$ concentrations significantly declined from the fringing mangroves to tidal channel at Sweeting's Cay, Bahamas. A similar trend of increasing leaf C:P ratios with distance from mangrove islands (30 to $120 \mathrm{~m}$ ) was found for T. testudinum by Fourqurean et al. (1992a, see present Fig. 7) in Florida Bay. This gradient may point to 1 or more components of the mangrove habitat (fauna, remineralization, detrital input, nutrient mobilization) as providing $\mathrm{P}$ for the seagrass community. Although in our study and in Florida Bay, the specific source of nutrients was not quantitatively defined, a biotic component is likely to contribute nutrients to carbonate systems with little terrigeneous sediment inputs. Fourqurean et al. (1992a) attributed seagrass nutrient enrichment to the presence of bird rookeries on adjacent mangrove islands. A nutrient subsidy may have also been present at our site at Sweeting's Cay, however controlled by high fish abundance in the fringe mangrove zone rather than the presence of bird rookeries. In tropical clear oligotrophic waters, fish abundances are often extremely high among the proproots of fringe mangroves (Robertson \& Duke 1987 , Thayer et al. 1987, Pinto \& Punchihewa 1996), and may be a source of nutrients.

Nutrients associated with organic matter in the sediments may also have contributed to inorganic nutrients within the mangrove fringe. High water column nutrients and high sediment respiration rates within the fringing mangroves suggest elevated microbial remineralization activity. Higher sediment metabolic rates in the mangrove fringe may have led to increased nutrient recycling relative to lagoon and channel sites. However, preliminary sediment mineralization experiments $(2 \mathrm{wk}$ incubations at ambient sediment temperature, $27^{\circ} \mathrm{C}$ ) conducted with sediment from the Bahamas sites (0 to $5 \mathrm{~cm}$ depth) did not indicate significantly higher extractable $(2 \mathrm{M} \mathrm{KCl})$ inorganic $\mathrm{P}$ or $\mathrm{N}$ from mangrove sediments compared to the other sites (data not presented). 
Seagrass tissue C:P and C:N molar ratios, a timeintegrated measure of nutrient acquisition, do suggest that there is greater nutrient availability to seagrass tissues and epiphytes at sites adjacent to the fringing mangroves. Interestingly, while these nutrient trends were significant, they did not result in greater community NPP rates at sites closer to the mangroves. Seagrass beds adjacent to mangroves in Gazi Bay, Kenya, similarly showed no increase in NPP (plastocrone interval method) compared to beds in a central lagoon or reef site (Hemminga et al. 1995). Hemminga et al. (1995) further found no significant relationship between proximity to mangroves and nutrient composition $(\mathrm{C}: \mathrm{N}: \mathrm{P})$ of the dominant seagrass Thalassodendron ciliatum, in contrast to our results and those of Fourqurean et al. (1992a). However, the Kenya site may not have been as P-limited as those from the Bahamas or South Florida, because T. ciliatum tissue $\mathrm{C}: \mathrm{P}$ ratios were low, $<605$, whereas the ratios in plants at our sites ranged significantly higher (Fig. 5). The authors argue that, based on a review of seagrass leaf nutrient content (Duarte 1990), T. ciliatum would be under-saturated with respect to $\mathrm{P}$ and $\mathrm{N}$ at 0.2 and $2 \%$, respectively. Tissue $\mathrm{P}$ content of $T$. ciliatum, albeit low based on Duarte's review, was approximately 2 times the concentrations that we found for Thalassia testudinum in the Bahamas (0.09 to 0.12) and observed by

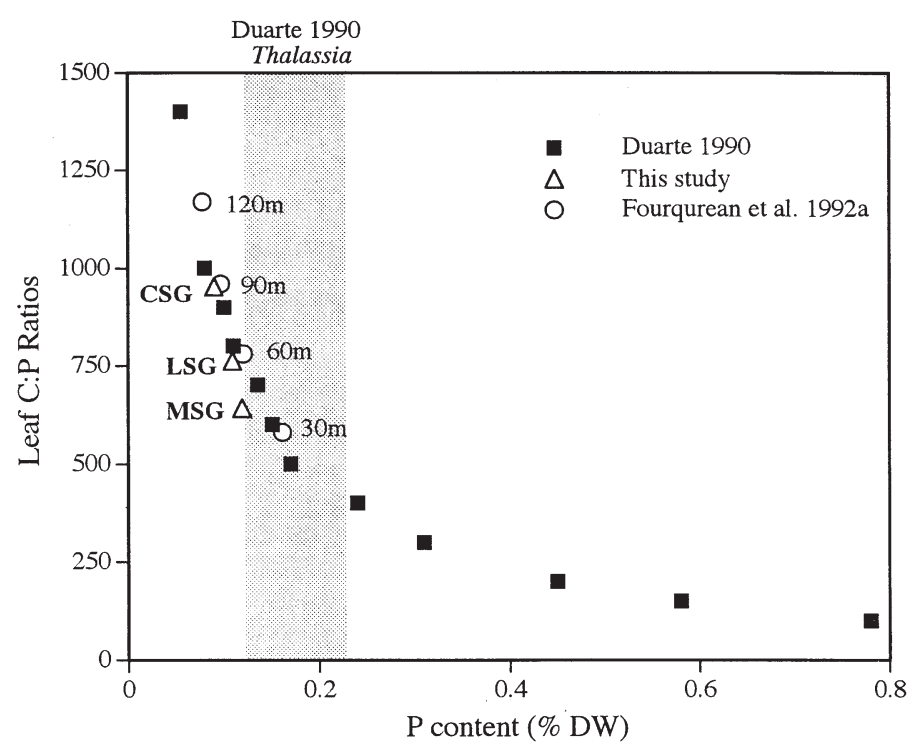

Fig. 7. Molar C:P ratios of seagrass leaves as a function of $P$ content. A review of 27 seagrass species by Duarte (1990) is compared to Thalassia testudinum in Florida Bay at various distances from a mangrove island determined by Fourqurean et al. (1992a) and to those found in the Bahamas in the fringe mangrove (MSG), lagoon (LSG), and channel (CSG) seagrass sites. Shaded area: range of values for Thalassia spp. reviewed by Duarte. DW: dry weight
Fourqurean et al. (1992a) in Florida Bay (0.08 to 0.16, Fig. 7). Erftemeijer et al. (1993) also compared seagrass GPP rates at sites with variable nutrient inputs in Indonesia, and found that oligotrophic carbonate-dominated reef sites had GPP rates similar to those of coastal sites characterized by terrigenous sediments. Thus, a pattern of increased phophorus in seagrasses adjacent to fringing mangroves has been observed in tropical carbonate sediments, but this tissue nutrient gradient, even when present, does not necessarily enhance community NPP rates.

Regardless of inter-site differences, all seagrass sites had similarly high NPP rates (1.65 to $2.29 \mathrm{~g} \mathrm{C} \mathrm{m}^{-2} \mathrm{~d}^{-1}$ ), and seagrasses dominated lagoon net and gross primary production. GPP rates (3.82 to $4.96 \mathrm{~g} \mathrm{C} \mathrm{m}^{-2} \mathrm{~d}^{-1}$ ) were within the upper range reported for the tropical seagrass Thalassia hemprichii (GPP 2.5 to $3.6 \mathrm{~g} \mathrm{C} \mathrm{m}^{-2}$ $\mathrm{d}^{-1}$, Erftemeijer et al. 1993) and close to the maximum rates measured for Indonesian grassbeds $\left(5 \mathrm{~g} \mathrm{C} \mathrm{m}^{-2} \mathrm{~d}^{-1}\right.$, Lindeboom \& Sandee 1989), using a similar sampling approach. In Laguna Madre, Texas, a temperate site, T. testudinum maximum GPP rates in the summer $(1.76$ to $2.80 \mathrm{~g} \mathrm{C} \mathrm{m}^{-2} \mathrm{~d}^{-1}$, Ziegler \& Benner 1998) were lower than those we measured during May. GPP rates for $T$. testudinum beds in the tropics and temperate sites are higher than those reported for temperate beds including seagrass, epiphytes, and sediments dominated by Zostera marina (2.99 g C m $\mathrm{g} \mathrm{d}^{-1}$, Murray \& Wetzel 1987; <2.00 g C m${ }^{-2} \mathrm{~d}^{-1}$, see review in Ziegler \& Benner 1998). Bahamas seagrass beds had slightly higher GPP rates compared to other macrophyte-dominated coastal ecosystems $\left(2.86 \mathrm{~g} \mathrm{C} \mathrm{m}^{-2} \mathrm{~d}^{-1}\right.$, Gattuso et al. 1998).

Gattuso et al. (1998) reviewed the metabolism of coastal ecosystems including estuaries, macrophytedominated, coral reef, saltmarshes, and mangroves and found $\mathrm{P}: \mathrm{R}$ ratios ranging from 0.8 to 1.4 , lower than the $P: R$ ratios we observed in the mangrove (1.6), lagoon (1.7), and channel (2.5) sites in the Bahamas. Although the Bahamas seagrass beds at Sweeting's Cay were highly autotrophic, not all tropical seagrass beds exhibit similarly high rates of NPP. Indonesian seagrass beds at both reef and coastal sites had NPP rates of $<1 \mathrm{~g} \mathrm{C} \mathrm{m}^{-2} \mathrm{~d}^{-1}$, with $\mathrm{P}: \mathrm{R}$ ratios averaging $<1$ (Erftemeijer et al. 1993). Hence, no generalizations about patterns of $\mathrm{P}: \mathrm{R}$ can be made for tropical seagrass communities.

High net autotrophy within seagrass communities provides carbon to support heterotrophy in the water column (Ziegler \& Benner 1998). At our site, excess carbon from the seagrass community may support water column heterotrophic activity both in the lagoon and on the adjacent reef and hard-bottom communities through tidal export. An absence of accumulated organic carbon at the Bahamas seagrass sites supports 
this conjecture. Thus, Bahamas seagrasses in shallow lagoons that extend for several kilometers, such as at Sweeting's Cay, and those spanning the Bahamas Banks may act as an important carbon source in this oligotrophic region.

In addition to seagrasses, epiphytic algae on seagrass and mangrove prop-roots may also provide carbon to primary consumers on a site-specific basis. Rates of NPP for seagrass epiphytes and prop-root algae (5.22 \pm 1.44 and $\left.8.54 \pm 6.41 \mathrm{~g} \mathrm{C} \mathrm{kg}^{-1} \mathrm{~d}^{-1}\right)$ approached those for seagrasses $\left(10.49 \pm 3.76\right.$ to $\left.13.18 \pm 5.68 \mathrm{~g} \mathrm{C} \mathrm{kg}^{-1} \mathrm{~d}^{-1}\right)$ in the Bahamas lagoon. These community NPP rates fall within the lower range found for algal species incubated without the heterotrophic community. Burkholder \& Almodóvar (1973) measured ${ }^{14} \mathrm{C}$ uptake rates of 14 different macroalgal species growing on mangrove prop-roots in Puerto Rico. They estimated a wide range of NPP rates (2.9 to $46.0 \mathrm{~g} \mathrm{C} \mathrm{kg}^{-1} \mathrm{~d}^{-1}$, with an average rate of $14.7 \mathrm{~g} \mathrm{C} \mathrm{kg}^{-1} \mathrm{~d}^{-1}$ ) and estimated GPP rates to be 2 times higher, using oxygen flux measurements. Thus, macroalgae may be an important component of carbon production in tropical lagoons, although few studies have quantified algal NPP in these systems.

High water clarity in oligotrophic environments such as in the Bahamas, Puerto Rico, and some sites in Florida may restrict fishes and other consumers to refuges among fringing mangrove prop-roots (Robertson \& Duke 1987, Thayer et al. 1987, Pinto \& Punchihewa 1996). This spatial isolation may force some primary consumers to feed on epiphytic algae growing on prop-roots and seagrass epiphytes adjacent to fringing mangroves (pers. obs.), at least during daylight hours. For this reason, and because of the fact that net algal production rates are high, epiphytic algae growing in narrow bands within and adjacent to mangrove proproots may be significant sources of carbon to food webs of tropical lagoons. Also, the nutritional value of seagrasses has been suggested to be lower than that of algae for primary consumers because of the high cellulose, hemicellulose and lignin content of seagrass tissues (Bjorndal 1980, Klumpp \& van der Valk 1984). This high fiber content can limit labile protein acquisition by consumers via physical and chemical digestive processes, even when total seagrass and algal protein content are similar (Klumpp et al. 1989). Thus, while seagrasses have large spatial coverage in tropical lagoons, algae associated with fringing mangroves may be important for some primary and secondary consumers.

In conclusion, based on sediment, water column nutrient patterns and tissue stoichiometry, seagrasses close to the mangrove fringe appeared to have greater access to nutrients than seagrasses in the central channel of the lagoon. While we identified spatial nutrient patterns in this tropical lagoon, further work is required to identify the specific source of these nutrients. Regardless of the tissue nutrient patterns, however, seagrass community NPP was similar along the entire transect from the fringe mangrove to channel site. At all sites, seagrass productivity was high, which may indicate that within a small spatial gradient, such as that in our study, effects of decreasing nutrient availability are overcome by efficient recycling within the seagrass community, either through microbial processes and/or biotic processing by higher trophic level organisms.

High P:R ratios of the seagrass beds found in our Bahamas study and the heterotrophic water column identify these seagrass communities as important sites of carbon fixation and potential sources of carbon to the water column and adjacent systems. High primary production rates of submerged autotrophs within the fringing mangroves, including benthic and prop-root algae, an under-recognized autotrophic component of tropical lagoons, may also be important contributors to lagoon primary production.

Acknowledgements. We acknowledge Florida Institute of Oceanography for ship time in the Bahamas, the crew of the RV 'Bellows', and Florida Atlantic University (FAU) for grant support through a Research Initiation Award. We thank the Bahamian government Department of Fisheries for allowing us to conduct this research. Laboratory assistance was provided by several undergraduate and graduate students in the Aquatic Plant Ecology Lab at FAU. We recognize the South Florida Water Management District for their support on this project.

\section{LITERATURE CITED}

Alongi DM (1998) Coastal ecosystem processes. CRC Press, Boca Raton

APHA (American Public Health Association) (1995) Standard methods for the examination of water and wastewater, 19th edn, APHA, Washington, DC

Benner R, Hodson RE (1985) Microbial degradation of the leachable and lignocellulose components of leaves and wood from Rhizophora mangle in a tropical mangrove swamp. Mar Ecol Prog Ser 23:221-230

Bjorndal KA (1980) Nutrition and grazing behavior of the green turtle Chelonia mydas. Mar Biol 56:147-154

Burkholder PR, Almodóvar LR (1973) Studies on mangrove algal communities in Puerto Rico. Flo Sci 36:66-74

Capone DG (1983) Benthic nitrogen fixation. In: Carpenter EJ, Capone DG (eds) Nitrogen in the marine environment. Academic Press, New York, p 105-137

Duarte CM (1990) Seagrass nutrient content. Mar Ecol Prog Ser 67:201-207

Erftemeijer PLA, Osinga R, Mars AE (1993) Primary production of seagrass beds in South Sulawesi (Indonesia): a comparison of habitats, methods and species. Aquat Bot 46:67-90

Fourqurean JW, Zieman JC, Powell GVN (1992a) Phosphorus limitation of primary production in Florida Bay: evidence 
from C:N:P ratios of the dominant seagrass Thalassia testudinum. Limnol Oceanogr 37:162-171

Fourqurean JW, Zieman JC, Powell GVN (1992b) Relationships between porewater nutrients and seagrasses in a subtropical carbonate environment. Mar Biol 114:57-63

Gattuso JP, Frankignoulle M, Wollast R (1998) Carbon and carbonate metabolism in coastal aquatic ecosystems. Annu Rev Ecol Syst 29:405-34

Hemminga MA, Gwada P, Slim FJ, de Koeyer P, Kazungu J (1995) Leaf production and nutrient contents of the seagrass Thalassodendron ciliatum in the proximity of a mangrove forest. Aquat Bot 50:159-170

Jensen HS, McGlathery KJ, Marino R, Howarth RW (1998) Forms and availability of sediment phosphorus in carbonate sand of Bermuda seagrass beds. Limnol Oceanogr 43: 799-810

Klumpp DW, van der Valk A (1984) Nutritional quality of seagrasses (Posidonia australis and Heterozostera tasmanica): comparison between species and stages of decomposition. Mar Biol Lett 5:67-83

Klumpp DW, Howard RK, Pollard DA (1989) Trophodynamics and nutritional ecology of seagrass communities. In: Larkum AWD, McComb AJ, Shepard SA (eds) Biology of seagrasses: a treatise on the biology of seagrasses with special reference to the Australian region. Elsevier Press, New York, p 394-457

Lapointe BE (1987) Phosphorus- and nitrogen-limited photosynthesis and growth of Gracilaria tikvahiae (Rhodophyceae) in the Florida Keys: an experimental field study. Mar Biol 93:561-568

Lapointe BE (1989) Macroalgal production and nutrient relations in oligotrophic areas of Florida Bay. Bull Mar Sci 44: 312-323

Lindeboom HJ, Sandee AJJ (1989) Production and consumption of tropical seagrass fields in eastern Indonesia measured with bell jars and microelectrodes. Neth J Sea Res 23:181-190

Littler MM, Littler DS, Taylor PR (1983) Evolutionary strategies in a tropical barrier reef system: functional-form groups of marine macroalgae. J Phycol 19:229-237

Murray L, Wetzel RL (1987) Oxygen production and consumption associated with the major autotrophic compo-

Editorial responsibility: Kenneth Heck (Contributing Editor), Dauphin Island, Alabama, USA nents in two temperate seagrass communities. Mar Ecol Prog Ser 38:231-239

Odum EP (1971) Fundamentals of ecology. WB Saunders Co, Philadelphia

Pérez M, Romero J (1993) Preliminary data on alkaline phosphatase activity associated with Mediterranean seagrasses. Bot Mar 36:499-502

Pinto L, Punchihewa NN (1996) Utilization of mangroves and seagrasses by fishes in Negombo Estuary, Sri Lanka. Mar Biol 126:333-345

Powell GVN, Kenworthy WJ, Fourqurean JW (1989) Experimental evidence for nutrient limitation of seagrass growth in a tropical estuary with restricted circulation. Bull Mar Sci 44:324-340

Powell GVN, Fourqurean JW, Kenworthy WJ, Zieman JC (1991) Bird colonies cause seagrass enrichment in a subtropical estuary: observational and experimental evidence. Estuar Coast Shelf Sci 32:567-579

Randall JM, Day JW Jr (1987) Effects of river discharge and vertical circulation on aquatic primary production in a turbid Louisiana (USA) estuary. Neth J Sea Res 21:231-242

Robertson AI, Duke NC (1987) Mangroves as nursery sites: comparisons of the abundance and species composition of fish and crustaceans in mangroves and other nearshore habitats in tropical Australia. Mar Biol 96:193-205

Shaffer GP, Onuf CP (1985) Reducing the error in estimating annual production of benthic microflora: hourly to monthly rates, patchiness in space and time. Mar Ecol Prog Ser 26: 221-231

Short FT, Davis MW, Gibson RA, Zimmerman CF (1985) Evidence for phosphorus limitation in carbonate sediments of the seagrass Syringodium filiforme. Estuar Coast Shelf Sci 20:419-430

Short FT, Dennison WC, Capone DG (1990) Phosphorus-limited growth of the tropical seagrass Syringodium filiforme in carbonate sediments. Mar Ecol Prog Ser 62:169-174

Thayer GW, Colby DR, Hettler WF Jr (1987) Utilization of the red mangrove prop-root habitat by fishes in south Florida. Mar Ecol Prog Ser 35:25-38

Ziegler S, Benner R (1998) Ecosystem metabolism in a subtropical, seagrass-dominated lagoon. Mar Ecol Prog Ser $173: 1-12$

Submitted: February 18, 2000; Accepted: January 11, 2001 Proofs received from author(s): August 22, 2001 